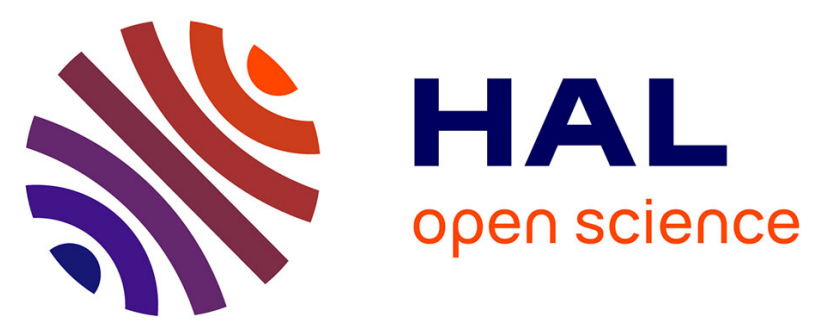

\title{
Influence of grain size distribution on critical state of granular materials
}

\author{
Gang Li, Carlos Ovalle, Christophe Dano, Pierre-Yves Hicher
}

\section{To cite this version:}

Gang Li, Carlos Ovalle, Christophe Dano, Pierre-Yves Hicher. Influence of grain size distribution on critical state of granular materials. Second International Symposium on Constitutive Modeling of Geomaterials: Advances and New Applications (IS-Model2012), Oct 2012, Pékin, China. 10.1007/9783-642-32814-5_25. hal-01008326

\section{HAL Id: hal-01008326 \\ https://hal.science/hal-01008326}

Submitted on 30 May 2017

HAL is a multi-disciplinary open access archive for the deposit and dissemination of scientific research documents, whether they are published or not. The documents may come from teaching and research institutions in France or abroad, or from public or private research centers.
L'archive ouverte pluridisciplinaire HAL, est destinée au dépôt et à la diffusion de documents scientifiques de niveau recherche, publiés ou non, émanant des établissements d'enseignement et de recherche français ou étrangers, des laboratoires publics ou privés.

\section{(c)(1)}

Distributed under a Creative Commons Attribution| 4.0 International License 


\title{
Influence of Grain Size Distribution on Critical State of Granular Materials
}

\author{
Gang Li, Carlos Ovalle, Christophe Dano*, and Pierre-Yves Hicher \\ Research Institute in Civil and Mechanical Engineering \\ Ecole Centrale de Nantes \\ UMR CNRS 6183, Nantes, France \\ christophe.dano@ec-nantes.fr
}

Summary. This paper aims to investigate the influence of grain size distribution (GSD) on the critical state of Hostun sand. Drained triaxial tests were conducted on saturated specimens with different GSD $\left(\mathrm{C}_{\mathrm{u}}=1.4,5,10,20\right)$ under different confining pressures $(100,200,400 \mathrm{kPa})$. The experimental results highlight that the critical state of the tested sand predominantly depends on its GSD.

Keywords: grain size distribution, critical state, triaxial tests.

\section{Introduction}

Since the pioneering work of Roscoe and Schofield (1958), the critical state concept has been developed and largely regarded as a fundamental framework for the development of constitutive models for soils. Based on this concept, lots of studies have been conducted on crushable soils (see for example Daouadji and Hicher, 1997), which have shown that the GSD of the soil changes during its lifetime by crushing of particles, leading to an increase of the coefficient of uniformity $\mathrm{Cu}$. These changes influence the basic constitutive properties of the material, in particular the properties such as the critical state which is dependent on the particle size distribution at a given point of the loading history. As the fine content increases and the soil becomes better graded, it has been experimentally shown that the critical state line moves downwards (Biarez and Hicher 1994). Based on these new findings, some new models for crushable soils have been developed (Daouadji et al. 2001). Also, by means of discrete element method (DEM), Wood and Maeda (2007) showed the dependence of the critical state of granular materials on their initial GSD. However, so far, no detailed experimental data confirm these findings obtained by DEM.

This study aims to investigate the influence of initial particle GSD of a granular material on its mechanical behavior in terms of critical state and stress-strain relationship. A series of drained triaxial tests were performed on specimens of Hostun sand. Due to the high strength of Hostun sand particles, grain breakage may be considered as being negligible during shearing under testing loading conditions, permitting to maintain the same GSD all along the mechanical loading. 


\section{Testing Program}

Samples with different GSD, corresponding to different coefficients of uniformity $C_{u}\left(d_{60} / d_{10}\right)$ varying from 1.4 to 20 , with identical mean grain size $\mathrm{d}_{50}$, were tested (Fig.1a). Three effective confining pressures $(\mathrm{CP}=100 \mathrm{kPa}, 200 \mathrm{kPa}, 400 \mathrm{kPa})$ were applied. All specimens were prepared by the moist tamping method (Ishihara 1993 ) in order to obtain very loose specimens.
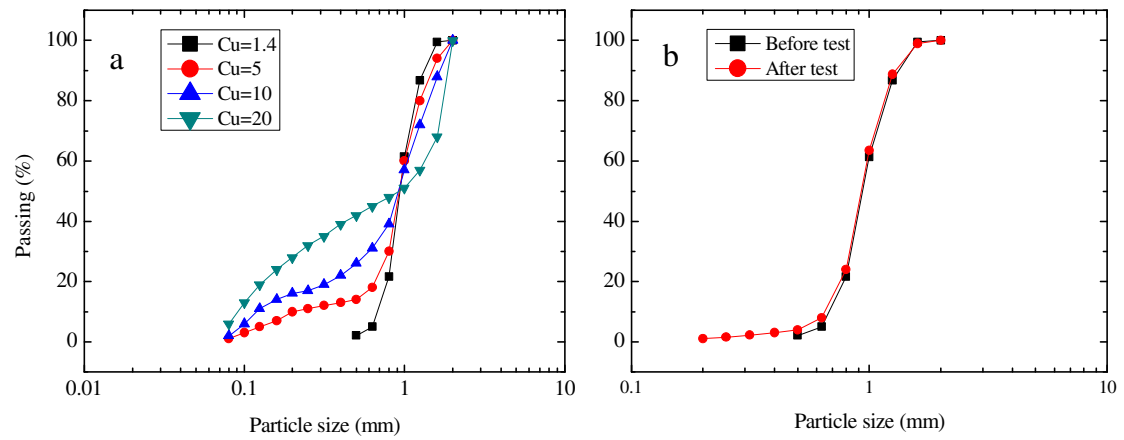

Fig. 1. (a) Particle size distribution; (b) $\mathrm{GSD}\left(\mathrm{C}_{\mathrm{u}}=1.4 \mathrm{CP}=400 \mathrm{kPa}\right)$ before and after test

In order to confirm the assumption of no particle breakage occurring during testing, grain size distributions were systematically measured at the end of each test. As an example, the grain size distribution of one specimen $\left(C_{u}=1.4\right.$ and confining pressure $=400 \mathrm{kPa}$ ), most prone to grain breakage among all the tested specimens, before and after the test is presented (Fig.1b). It shows that no global grain occurred; only a small amount of fines was produced by attrition.

\section{Results and Discussions}

Responses of specimens with different initial void ratios under triaxial compression at the same confining pressure are shown in Fig.2. It can be observed that the two specimens have the same tendency of contracting until the critical state is reached. However, the denser specimen appears less contractive. Although the initial void ratios are different, both specimens reach the same ultimate strength, corresponding to a same final void ratio at critical state.

The comparison of the critical state lines (CSL) obtained for different $C_{u}(1.4$, 5, 10 and 20) in the $p^{\prime}-q$ plane is presented in Fig.3a. It can be concluded that the tested specimens exhibit a unique critical stress ratio $\left(M=q / p^{\prime}\right)$ upon compression regardless of GSD, except for the case of $C_{u}=20$ which shows a slight deviation with higher maximum stress ratio. The uniqueness of the critical stress ratio confirms that the shear resistance is not influenced by the change in GSD (Bandini and Coop, 2011). The differences obtained for $C_{u}$ equals 20 , may be due to the heterogeneity of the specimens during preparation, resulting in higher void ratio in the upper part of the sample due to some segregation of the finer part. 


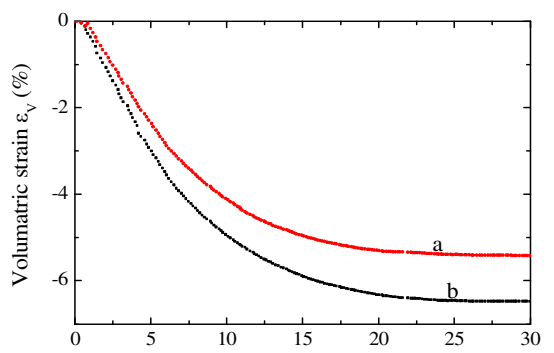

$\mathrm{a} \mathrm{Cu}=1.4 \mathrm{CP}=100 \mathrm{kPa} \mathrm{e}_{0}=0.8$

$\mathrm{b} \mathrm{Cu}=1.4 \mathrm{CP}=100 \mathrm{kPa} \mathrm{e}=0.85$
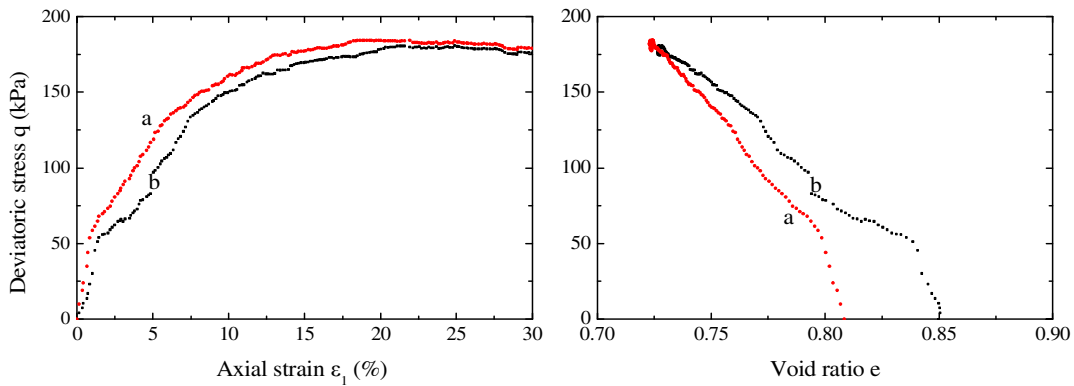

Fig. 2. Mechanical response of specimen with different $\mathrm{e}_{0}$

The CSL in the $e-\log p^{\prime}$ plane for specimens with different $C_{u}$ is presented in Fig. $3 \mathrm{~b}$. It can be found that the location of the CSL varies with the change of $C_{u}$. The higher the $C_{u}$ value, the lower the location of the CSL. In other words, a well graded material has a smaller void ratio at critical state than a badly graded one.
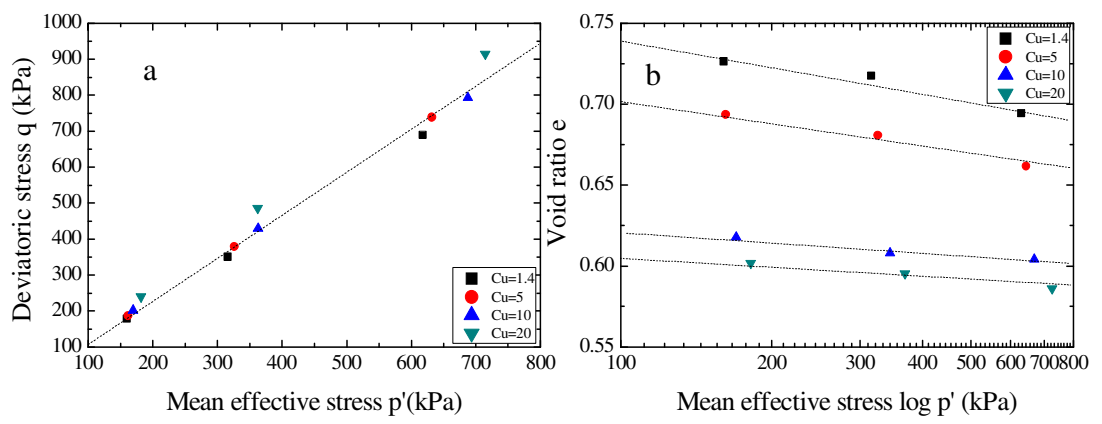

Fig. 3. (a)Critical state lines in p'- q space; (b) Critical state lines in e-log p' space

\section{Conclusions}

Although the factors influencing the critical state of soils have been widely investigated by means of numerical and experimental approaches, there is still a lack of detailed experimental data addressing the influence of the grain size distribution (GSD) on the critical state of sandy soils. Therefore, the objective of this 
experimental study was to investigate the influence of initial GSD on the mechanical properties of non-crushable soils. A series of conventional consolidateddrained triaxial compression tests were carried out on loose saturated Hostun sand specimens with different coefficients of uniformities $C_{u}(1.4-20)$. This sand could be regarded as non-crushable under loading conditions used in this study. The experimental results highlight that the critical state of the tested specimens are significantly affected by the changes in GSD. A higher value of $C_{u}$ leads to a lower location of the critical state line (CSL) in the $e-\log p$ ' plane while the CSL in the $p^{\prime}-q$ plane appears unique regardless of the value of $C_{u}$. In other words, the GSD affects the void ratio at critical state but not the ultimate shear strength or friction angle at critical state.

\section{References}

[1] Roscoe, K.H., Schofield, A.N., Wroth, C.P.: On the Yielding of Soils. Géotechnique 8, 22-53 (1958)

[2] Daouadji, A., Hicher, P.-Y.: Modelling of grain breakage influence on mechanical behaviour of sand. In: Pietruszczak, Pande (eds.) Numerical Models in Geomechanics, Balkema, Rotterdam (1997) ISBN 905410886X

[3] Biarez, J., Hicher, P.-Y.: Elementary mechanics of soil behaviour. A.A. Balkema, Rotterdam (1994)

[4] Daouadji, A., Hicher, P.-Y., Rahma, A.: Modelling grain breakage influence on mechanical behaviour of granular media. European Journal of Mechanics, A/Solids 20, 113-137 (2001)

[5] Muir Wood, D., Maeda, K.: Changing GSD of soil: effect on critical states. Acta Geotechnica 3, 3-14 (2007)

[6] Ishihara, K.: Liquefaction and flow failure during earthquakes. Géotechnique 43(3), 351-415 (1993)

[7] Bandini, V., Coop, M.R.: The influence of particle breakage on the location of the critical state line of sands. Soils and Foundations 51(4), 591-600 (2011) 